\title{
A century of mathematical excellence at Spelman College
}

\section{Colm Mulcahy QCardColm}

\author{
Department of Mathematics, \\ Spelman College, Atlanta, GA \\ www.cardcolm.org
}

$$
5 \text { Jan } 2017
$$


The first documented mathematics major at Spelman graduated in 1929, and she went on to do a masters in math at the University of Wisconsin in Madison.

Since 1958, we've graduated $700+$ math majors. Many of these achieved excellence in academia, industry, and government, with several serving in leadership roles in colleges and universities. 
We'll survey some of these remarkable careers, as well as the history of Spelman's department of mathematics, whose teaching, mentoring, and special programs laid the foundation which this possible.

So far, 55+ of Spelman's grads have earned doctoral degrees in math or related fields.

That number shows every sign of growing at an increasing pace, and by 2029 we expect it to be much higher. 


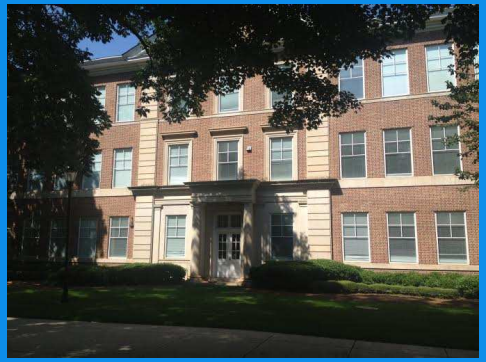

Tapley Hall-dedicated to Lucy Hale Tapley in 1925

"Founded in 1881, by and for women, Spelman College epitomizes the best that women's colleges can provide."

—Alma Ferguson Crockett, C'29 


\section{Spelman Dept of Math is built on Four Pillars}

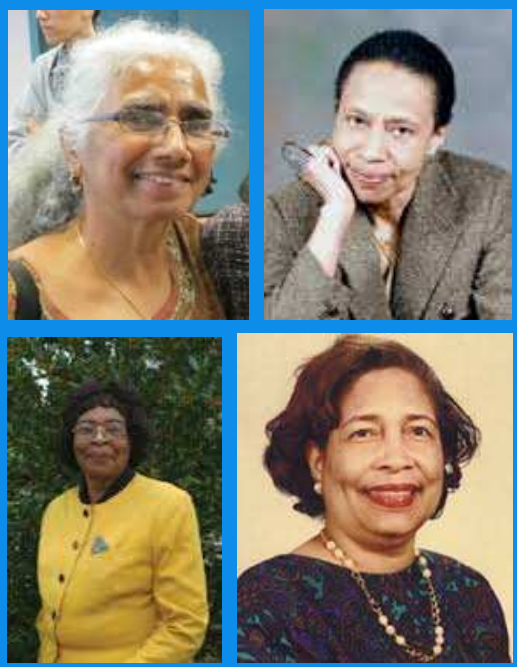



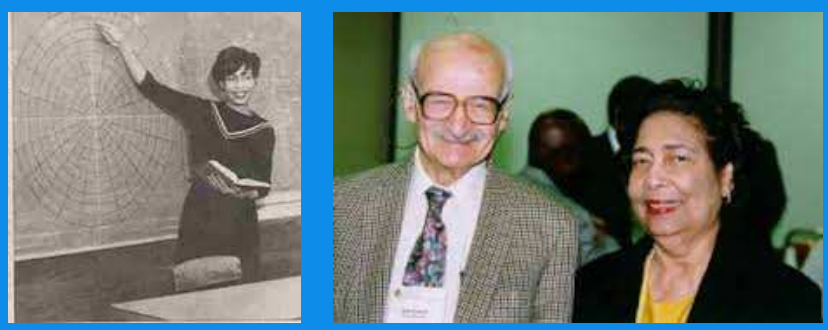

Dr. Etta Falconer (1933-2002, née Zuber), algebraist. Fisk BA (1953), U Wisconsin at Madison MSc (1955), Emory PhD (1969, "Quasigroups Invariant Under Isotopy").

Served Spelman 1965 to 2002. Chair, dean, etc. AWM-MAA MathFest Lecture now named after her. Spelman's annual Falconer lecture predates that. 


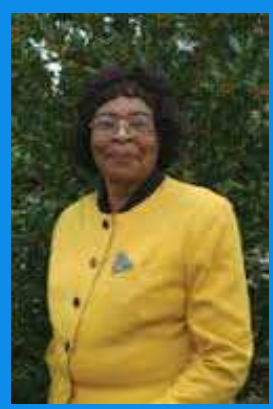

Dr. Gladys Glass (née Thomas, C'58). AU MSc (1959). GSU PhD (1982, "A study of mathematics anxiety among female college students").

Served Spelman 1959-2009.

Very active in issues related to education. 


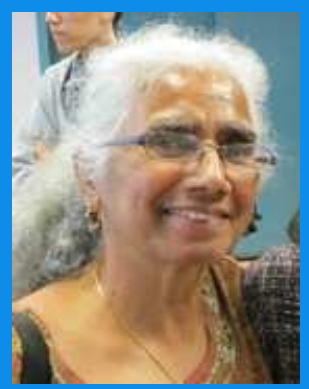

Dr. Nagambal Shah, statistician. U of Kerala BSc (1964) \& MSc (1966), U of Windsor PhD (1970, "Contributions to products of polykays").

Served Spelman 1972-2014.

Co-founder of StatFest; co-founder of Infinite Possibilities Conference (IPC). 


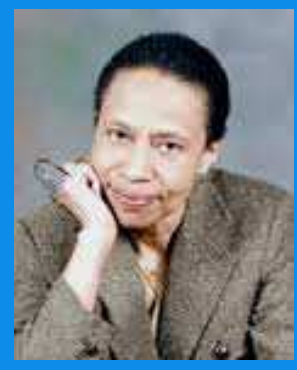

Dr. Sylvia Bozeman (née Trimble), analyst.

Alabama A\&M BSc (1968), Vanderbilt MSc (1970). Emory PhD (1980, "Representations of Generalized Inverses of Fredholm Operators").

Served Spelman 1974-2013. Chair.

\section{Co-founded EDGE Program.}




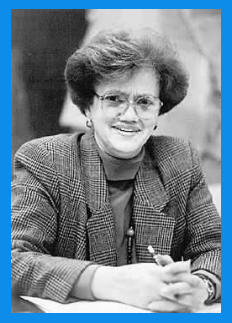

Dr. Shirley McBay (née Mathis). BA \& MS in Chem, AU MS in Math (1958), UGA PhD (1966, "Homology Theory of Metabelian Lie Algebras").

Served Spelman 1967-1975. Chair, dean.

Ran Quality Education for Minorities (QEM) program in Washington, DC, 1990-2016. 


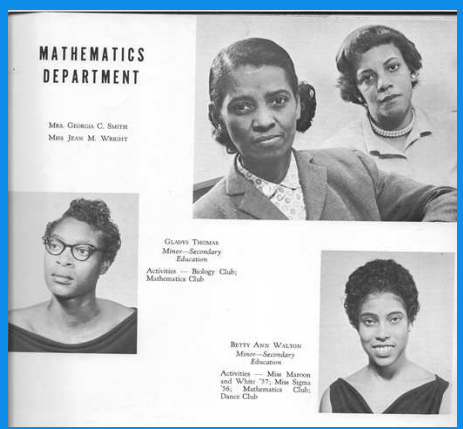

Dr. Georgia Smith (1909-1961, née Caldwell). Univ Kansas BSc \& MSc (1928 \& 1929). Served Spelman for most of 1929-1961. Chair. Univ of Pittsburg PhD (1961, "Some Results of the Anticenter of a Group"). 


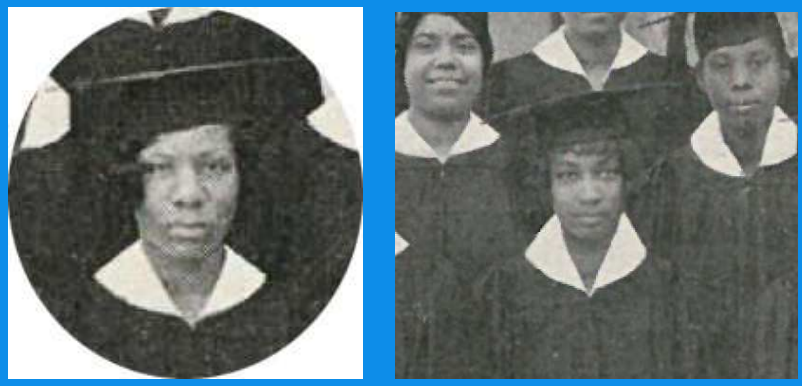

Alma Ferguson (later Crockett, C'29, 1908-2000).

Our first math major! From Pine Bluff (AR).

Univ of Wisconsin at Madison MSc (1931).

"I owe the world a woman, I shall earnestly strive to pay my debt"-from her HS yearbook in Arkansas. 
Spelman department of math today

Our math faculty includes Fred Bowers, Yewande Olubummo, and Jeffrey Ehme, all of whom have served for at least 25 years. Yewande and Jeff did long stints as department chair too.

21st century arrivals: Monica Stephens (C'91 and current dept chair), Tasha Inniss, Mohammed Tesemma, Joycelyn Wilson, Viveka Borum, Kiandra Johnson, Megan Cream, Bhikhari Tharu, and Math Lab Director Tiffanie Scruggs. 


\section{Spelman's early doctoral success stories}

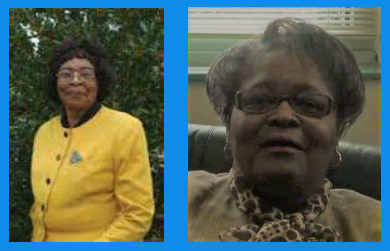

Dr. Gladys Glass (C'58), GSU PhD (1982, ed).

Dr. Josephine Davis (C'64), Rutgers PhD (1973, "Functions of a real variable: part of a mathematics curriculum for capable but poorly prepared college freshman"); career Albany State (dean) / York

College CUNY (president) / Saint Cloud State (VP)

/ Fort Valley State (dean) 


\section{Spelman's early doctoral success stories}

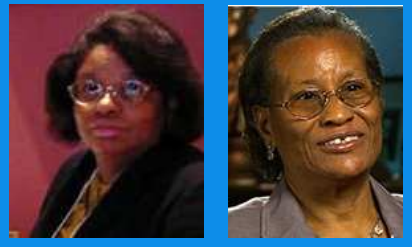

Dr. Andrea Lawrence (née Williams, C'70, degree from Purdue), GA Tech PhD (1993, CS), Spelman faculty (math \& CS) since 1983.

Dr. Roselyn Williams (C'72), FSU PhD (1988, "Finite dimensional Hopf algebras"); career Florida A\&M (chair). 


\section{Spelman's early doctoral success stories}
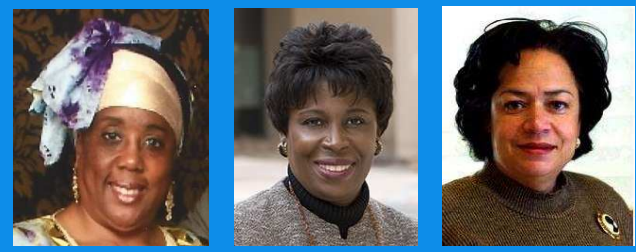

Dr. Deborah Najee-ullah (C'75), Virginia State PhD (1989, math ed); career GSU.

Dr. Denise Stephenson-Hawk (née Stephenson, aka Graves, C'76), Princeton Phd (1986, fluid dyn); career Bell Labs / CAU / Spelman / NCAR.

Dr. Teresa Edwards (C'76), Gatech PhD (1990, OR); career Spelman / Bennett / Georgia Gwinnett (chair in all). 


\section{Spelman's earliest doctoral success story}

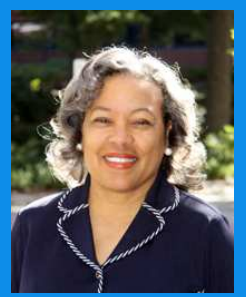

Dr. Daphne Smith (C'80), MIT PhD (1985, "Vapnik-Cervonenkis Classes and the Supremum Distribution of a Gaussian Process").

Career WellPoint / CVS / Alere Health. President NAASC.

Spelman trustee. 
Select other success stories (1980s)

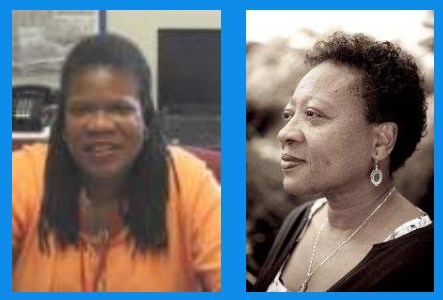

Dr. Elaine Terry (C'83), Howard PhD (1997, "Finite Sums and Products in Ramsey Theory"); career Saint Joseph's Univ in Philadelphia.

Dr. Patsy Davies (C'86), Berkeley MSc (1988), U Manchester PhD (2013, ed leadership); career in Sierra Leone \& UK, teaching math \& CS. 
Select other success stories (early 1990s)
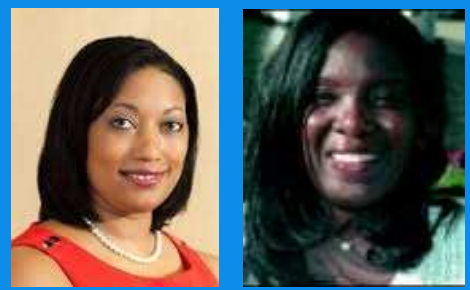

Dr. Karen King (C'91), U Maryland (College Park) PhD (1997, math ed); career San Diego State / Michigan State / NSF/ NYU / NCTM / NSF.

Dr. Stephanie Pace (1969-2009, née Jackson, C'91), U Maryland (C Park) PhD (2002, math ed). 


\section{Select other success stories (early 1990s)}
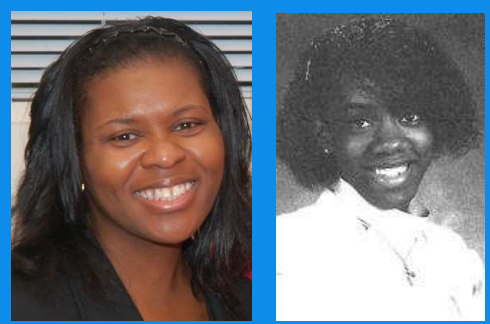

Dr. Monica Stephens (C'91), Brown PhD (1998, fluid dyn); career mostly at Spelman (dept chair). Dr. Angela Beauford (1969-2014, C'92), Univ of Pittsburgh (2009, EE); career included Spelman. 


\section{Select other success stories (early 1990s)}
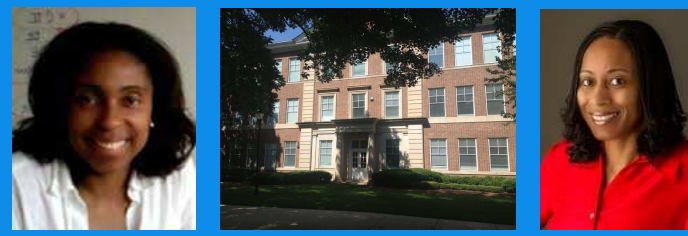

Dr. Ulrica Wilson (C'92), Emory PhD (2004, algebra); career mostly at Morehouse. Co-director of EDGE program.

Dr. Djuana Lea (née Pigford, C'93), NC State PhD (2004, OR); career Air Force Off Sci Research Dr. Afi Harrington (née Davis, C'93), NC State PhD (1997, OR); career Center for Naval Analyses / life coach 


\section{The Spelman Korean Conspiracy}
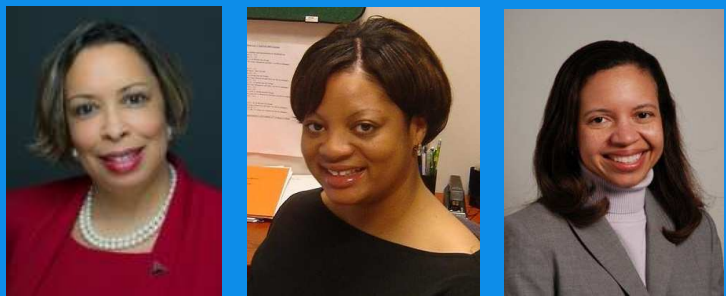

Dr. Kim Barnette (née Woodson, C'92), NC State PhD (2000, OR); career in Delta Decisions.

Dr. Kim Bennekin (née Rice, C'93), UGA PhD (2013, math ed); career Valdosta State / Spelman GA Perimeter.

Dr. Kim Weems (C'93), U Maryland (College Park) PhD (2000, stats); career NC State. 
Select other success stories (mid 1990s)
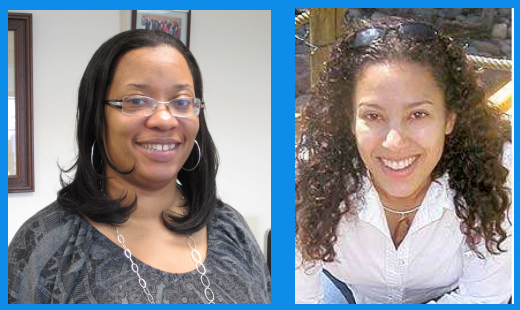

Dr. Leona Harris (C'95), NC State PhD (2001, $\mathrm{DE}$ ); career EPA / Bennett / College of NJ.

Co-founder of Infinite Possibilities Conference (IPC).

Dr. Tanya Moore (née Henneman, C'95), Berkeley PhD (2000, biostats); career UCLA / education policy advisor (San Francisco). Co-founder of Infinite Possibilities Conference (IPC). 
Select other success stories (mid 1990s)
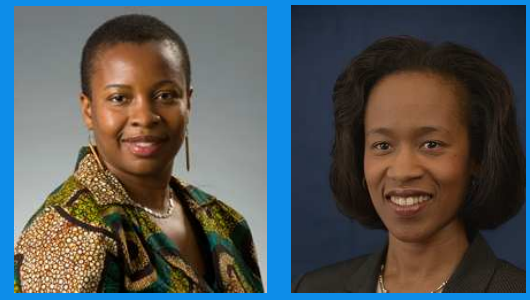

Dr. Denise (Tasha) Brewley (C'95), UGA PhD (2009, math ed); career Georgia Gwinnett.

Dr. Shona Morgan (née Davidson, C'95), NC State PhD (2001, OR); career NC A\&T State. 
Select other success stories (mid 1990s)
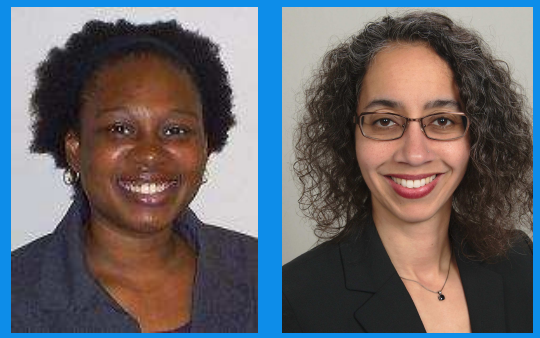

Dr. Kera Bell-Watkins (née Bell, C'96), NC State PhD (2006, CS); career NC State / GA Southern.

Dr. Talitha Washington (née Wangerin, C'96), U Conn PhD (2001, PDE); career Duke / College of New Rochelle / Univ Evansville / Howard. 
Select other success stories (late 1990s)
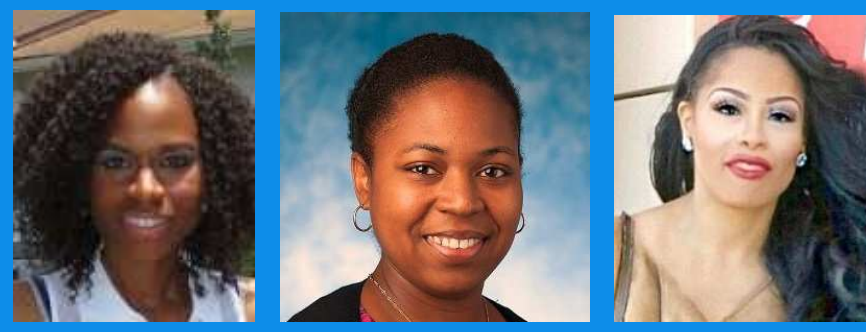

Dr. Ayana Moore (C'97), U Washington PhD (2005, biophysics); career Family Health Int.

Dr. Stacey Nicholls (C'98), U Maryland (C Park) PhD (2009, OR); career Anne Arundel Com College. Dr. Andrea Roberson (C'99), SUNY Stony Brook PhD (2010, stats). 


\section{Select other success stories (2000)}
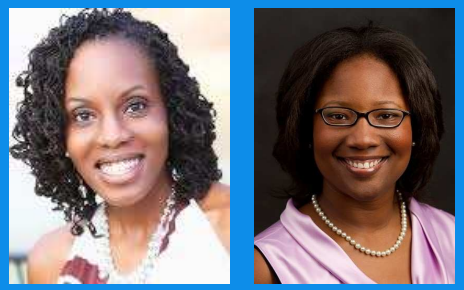

Dr. Valerie Jones (C'2000), Columbia PhD (2011, math ed); career APS / Ron Clark Academy.

Dr. Talithia Williams (née Daniels, C'2000), Rice PhD (2008, stats); career mostly at Harvey Mudd. 


\section{More Spelman grads with doctorates}

Monette Mclver (née Coleman, C'86), Kristen Lollis (née Charles, C'91), Alison Graves-Calhoun (née Graves, C'91), Carlotta Johnson (C'93), LaTondra Murray (C'93), Gail Jefferson (C'97), Jaclyn Conner (née Branner, C'99), Emile Lawrence (née Davie, C2001), Kiya Hamilton (C2001), Joyelle Harris (née Jones, C2001), Jamie Chatman (C2003), Evelyn

Thomas (C2003), Michelle Guinn (née Craddock, C2004), Jamila Mathias (C2004), Aminah Perkins (C2004), Ché Smith (C2005), Shelby Wilson (C2006), Anisah Nu'Man (C2009), Julia Anderson-Lee (C2010), ...

with Christina McIntosh, Monica Doriney, Karen Hicklin, Luvenia Hellams, and others to follow. 


\section{Other avenues explored}

Math majors are very versatile-and employable -being quick-thinking, and rational and logical problem solvers, both by nature and training.

Our grads have gone on have careers in a great variety of arenas using their primary degrees, often in conjunction with master's degrees in related fields. Many others have pursued medicine or law.

Spelman math grads can be found teaching, at middle and high school, or colleges, or working in statistics, bioinformatics, analytics, computer science, IT, engineering, business, and government. 


\section{Spelman math majors can do anything}

Althea Althea Ginn DeLisser (C'74) is President at Komatzu Software.

Dr. Deborah Prothrow-Stith (C'76) has had a very impressive career in public health. She has authored 4 books and received 10 honorary degrees.

Andrea Battle Sims (C'78) has master's from Wharton, is VP of Waters Consulting in Dallas.

Sarah Yeary (C'83) is an air traffic control expert. 
Spelman math majors can do anything

Wynne Stovall-Johnson (C'88) teaches math at Chestnut Hill College and has a 2009 article "I've Never Been Good At Reading."

Adrienne Nasir (née Baucom, C'91) is Assistant Principal at Howard County Public School System (D.C. Metro Area).

Dionne Ferguson (C'92) worked US Peace Corps 1994-2001, then at Good Journey Development Foundation, greater St. Louis area.

Mary Randle (C'93) went from math to acting and singing. Her stage credits include "The Lion King" and "Hollow Man." 


\section{Spelman math majors can do anything}

Alia Jones (C'95) is a distinguished and successful Broadway \& West End producer.

Malaika Mitchell (née Moses, C'97), daughter of Bob Moses, is now at Pearson Education.

Fabiola Aurelien (C'99) Founder \& Chief Consultant at A\&S Math Consultants.

Jeanne Johnson (née Roberts, C'2001) has dual careers in law and jewelry design.

Danielle Tillman (C'2003) is an expert at infusing architecture with social consciousness. 


\section{Spelman math majors can do anything}

Brittany Sanders (C'2006) has Carnegie Mellon MBA and is now back in her native Detroit making a difference.

La'Nita Ward (C'2006) is Director of Admissions and Marketing at Kindred Healthcare.

Lola Bolarinwa-Keita (C'2006) now works in banking in London.

Jamaica Pouncy (C'2010) is University Scholars program coordinator for Honors \& Undergrad Research (and National Fellowships Coordinator) for Texas A\&M. 


\section{Honorary Doctorates}
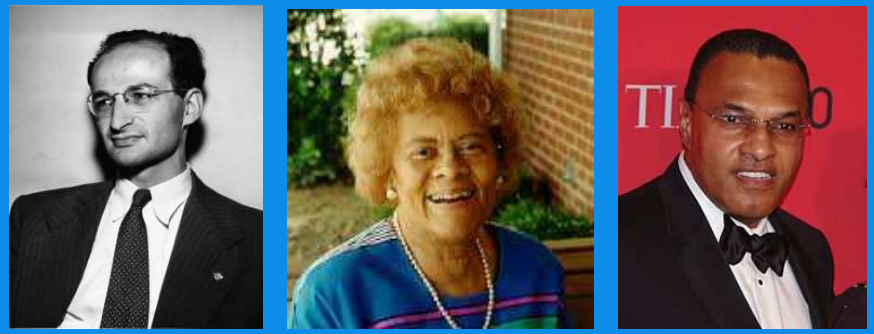

Spelman has bestowed honorary degrees on three mathematicians in honor of the extraordinary contributions they made and the influence they had.

Lee Lorch (1999)

Evelyn Boyd Granville (2006)

Freeman Hrabowski (2013) 
A century of mathematical excellence

The coming decades of Spelman women in math will be led by some of the above, as well as recent grads, and current and future math majors - some of them in this room.

They will all go forth and make their mark.

By 2029, many more of them will have doctorates in mathematics and related areas, and/or will make valuable contributions. 
Spelman women are born leaders

Please step aside-we don't want you to get hurt-and make way for the next generation of Spelman women making a difference!

Expect to see more Spleman women in leadership roles at MAA, AMS, SIAM, ASA, AWM, NAM, and beyond. 
Let no Spelman woman be a "hidden figure"!

Ensure that all relevant Spelman grads are fully represented at the Math Genealogy website.

1. Check if YOU are documented there.

2. Check if your appropriate students are.

3. Submit information for all missing people!

The same applies to grads of any AUC school, and any $\mathrm{HBCU}$, and ... .

Finally, please follow @Spelman_Math on Twitter. 